\title{
Realisms within Conundrum
}

The Personal and Authentic Appeal in Jia Zhangke's Accented Films

\section{Esther M. K. Cheung}

\section{OpenEdition \\ Journals}

\section{Electronic version}

URL: http://journals.openedition.org/chinaperspectives/5048

DOI: 10.4000/chinaperspectives.5048

ISSN: 1996-4617

\section{Publisher}

Centre d'étude français sur la Chine contemporaine

Printed version

Date of publication: 21 April 2010

ISSN: 2070-3449

Electronic reference

Esther M. K. Cheung, «Realisms within Conundrum », China Perspectives [Online], 2010/1 | 2010,

Online since 01 April 2013, connection on 28 October 2019. URL : http://journals.openedition.org/ chinaperspectives/5048; DOI : 10.4000/chinaperspectives.5048 


\title{
Realisms within Conundrum
}

\author{
The Personal and Authentic Appeal in sia Zhangke's Accented Films ${ }^{(1)}$
}

ESTHER M. K. CHEUNG

With persistent efforts on constructing personal and collective memories arising from the unprecedented transformations in post-socialist China, Jia Zhangke has produced an ensemble of realist films with an impressive personal and authentic appeal. This paper examines how his films are characterised by a variety of accents, images of authenticity, a quotidian ambience, and a new sense of materiality within the local-global nexus. Within a tripartite model of truth, identity, and performance, Jia's oeuvres demonstrate the powerful performativity of different modes of realism arising out of a state of conundrum when China undergoes a transition from planned economy into wholesale marketisation and globalisation.

\section{The appeal of Jia Zhangke's accented cinema}

F rom his first feature Xiao $W u$ (aka The Pickpocket, 1997) to 24 City (2008), Jia Zhangke's films have been characterised by an impressive personal and authentic appeal. As viewers, in about a decade's time we have observed an ongoing process of the director's negotiation with realism as a mode of film representation. With their focus on China's transition from planned economy to drastic processes of urbanisation and globalisation, Jia's films can be regarded as an observer's accounts, revealing the abrupt changes of a society in mutation. To say that Jia's films embody a personal and authentic appeal, I refer to two senses of meaning of the word "appeal." In the first instance, his films appeal to us because of the attractiveness of their personal touch and documentary feel. Viewers are impressed by his realistic portrayal of the minutiae of Chinese cities in violent transition, whether big or small, provincial or metropolitan. They are equally amazed by Jia's persistent effort to record personal and collective memories arising from the unprecedented changes in post-socialist China.

The second sense of "appeal" can be traced back to the etymological context of the law court where an earnest plea is made. More than a decade ago, when Jia's first short films and his debut feature $X_{i a o} W u$ emerged, he drew viewers' attention to the history of the 1980s, which could be regarded as a vacuum, as there were no visual records of his generation. ${ }^{(2)}$ In an interview, he claims that by "documentary," he refers to the "remembering of people's feelings and thoughts"; it follows that these visual memories are not con- fined to documentary realism. His films serve to write up a history of his generation:

I made these films because I wanted to compensate for what was not fulfilled. I must also emphasise that apart from the realist mode, there are other kinds of representation that can be called "visual memory"; for example, Dali's surrealist images in the early twentieth century can be grouped under psychological realism. ${ }^{(3)}$

With a sense of urgency, he appeals to viewers with an alternative, if not oppositional, film practice among contemporary Chinese films. It is a plea to invite both Chinese and global audiences to be more sympathetic toward those who are historically residual and who are being forgotten in the epic-historical vacuum. Born in 1970, Jia grew up in a different time and space than the Fifth Generation filmmakers. In his view, his predecessors have "monopolised" the discourse

1. This essay is developed from my earlier paper presented at the seminar on "Between Public and Private: A Space for Independent Chinese Cinema" organised by the Hong Kong International Film Festival and French Centre for Research on Contemporary China on 13 April 2009. It was fully funded by "Seed Funding for Basic Research" of the University of Hong Kong (from 1 April 2008 to 31 March 2010).

2. Jia's earlier short films include One Day in Beijing (1994), Xiao Shan Going Home (1995), and Du Du (1995). One Day in Beijing is a 15-minute documentary on tourists in Tiananmen Square, Xiao Shan Going Home, a narrative film with a documentary feel, tells the story of a cook who after being fired decides to leave Beijing and head back to his rural village for the Chinese New Year, and Du Du is about a female college student in Beijing who feels frustrated while facing lifechanging decisions.

3. Author unknown, "DV shi ziyou de_-Jia Zhangke tan shuzi shidai de dianying" (DV is free: Dialogues with Jia Zhangke on film in a digitalized era), Let's DV, at http://video.sina.com.cn/dv/2005-09-09/ 140610696.html. 
of suffering derived from the Cultural Revolution, turning it into something spectacular, normative, and all-inclusive. ${ }^{(4)}$ What is more, many of them gained an international reputation and later state approval by turning the function of film into the mere depiction of legends, historical traumas, and more recently glamorous epics (da pian). Jia, on the other hand, believes in realism as an effective strategy that generates "the effects of the real" in order to counter the tendency of dehistoricisation in film art. Growing up in post-Mao China, he and other filmmakers of the Urban Generation seek to articulate a different structure of feeling that is rooted in the deeply contextualised and historicised sensibility of a mutating moment. ${ }^{(5)}$ This approach to cinematic art has had an enormous appeal to not only Chinese viewers of their generation but also those Chinese intellectuals who are involved in debates on modernity in post-Mao China.

Although these new filmmakers do not form an organised movement, they speak to each other through similar concerns in both form and content. Critics have often noticed the affinity between Jia and the new documentarists since the late 1980s. For example, Jia's earlier films can be compared to Wu Wenguang's documentaries in terms of their treatment of time and their authentic appeal. ${ }^{(6)}$ Leading Chinese intellectuals from the magazine Dushu once held a panel discussion after Still Life's screening in Jia's hometown, Fenyang, to explore the film's realistic depictions of Chinese people's uprooted feeling within the rampant tides of modernisation. Participants included Wang Hui, Ouyang Jianghe, Cui Weiping, and others. ${ }^{(7)}$ Jia's preference for local knowledge and lived experience as well as exploration of the materialistic and anthropological dimensions of everyday life shape what we may now call "a Jia Zhangke accent," as he himself called it in an interview. ${ }^{(8)}$ It is the purpose of this paper to elucidate Jia's "accented cinema," which is a central notion in Hamid Naficy's study of alternative films in world cinema. ${ }^{(9)}$

In Naficy's An Accented Cinema: Exilic and Diasporic Filmmaking, accented films are alternative screen productions emerging from the margins of culture. In terms of their mode of production and distribution, they often operate outside the studio and mainstream industrial system. Similarly, when Jia's films first emerged, they were produced in a somewhat underground mode because they were not classified as state productions. This is not to suggest that his subject matter is particularly subversive, as the term "underground" (dixia) connotes. In fact, The World became Jia's first above-ground production in 2004, and Still Life (2006) not only garnered the Golden Lion at Venice but also won state approval for screening in China. As Yingjin Zhang and
Paul Pickowicz suggest, some of the young filmmakers in the 1990s prefer to be called "independent" ( $d u l i)$ directors to highlight their "independence from the state system of production, distribution, and exhibition" as well as to denote their personal style of filmmaking. ${ }^{(10)}$ Xiao Shan Going Home, for example, was not officially released in China but was first shown publicly at the Hong Kong Independent Short Film and Video Awards (IFVA) in 1996. Winning the top prize at IFVA, Jia became famous in the independent filmmaking circuit in Hong Kong.

His debut feature $X i a o W u$ was then produced by Hu Tong Communication, a production company based in Hong Kong and founded by Li Kit-ming in 1996, with the aim of promoting independent films. Later, Yu Lik-wai and Chow Keung also joined $\mathrm{Hu}$ Tong. Yu became Jia's cinematographer for most of his films, while Chow Keung has been closely involved with independent filmmaking and distribution in Hong Kong. With a modest budget of 400,000 yuan (about US\$50,000), Xiao Wu gained international recognition, and subsequently Jia's films began receiving funding from other countries, such as Japan, France, and Korea. The most notable is Jia's deal with Office Kitano Inc., the production house of Japanese filmmaker Takeshi Kitano, which has co-produced many major Jia films, including Platform (2000), Unknown Pleasures (2002), The World, and

4. Jia Zhangke, Jia xiang 1996-2008: Jia Zhangke dianying shouji (The thoughts of Jia: Jia Zhangke's notes on cinema), Beijing, Beijing University Press, 2009, p. 29.

5. See Zhang Zhen, "Introduction: Bearing Witness: Chinese Urban Cinema in the Era of 'transformation' (Zhuanxing)," in Zhang Zhen (ed.), The Urban Generation: Chinese Cinema and Society at the Turn of the Twenty-first Century, Durham and London, Duke University Press, 2007, pp. 1-48.

6. See Chris Berry, "Facing Reality: Chinese Documentary, Chinese Postsocialism," in Wu Hung et al. (ed.) The First Guangzhou Triennial: Reinterpretation: A Decade of Experimental Chinese Art (1990-2000), Guangzhou, Guangdong Museum of Art, Art Media Resources, 2002, pp. 121-30. Lu Xinyu, Ji lu Zhongguo: Dang dai Zhongguo xi ji Iu yun dong (Documenting China: Contemporary documentary movement in China). Beijing, Sanlian Shudian, 2003.

7. Ouyang Jianghe and Cui Weiping have since jointly published an edited volume titled Zhongguo du li dianying fang tan Iu (On the edge: Chinese independent cinema), Hong Kong, Oxford University Press, 2007, which includes a collection of interviews with contemporary independent filmmakers in China.

8. See also Stephen Teo, "Cinema with an Accent_-Interview with Jia Zhangke, director of Platform," Senses of Cinema, 15 (2001), in which Jia himself describes his own films as accented.

http://archive.sensesofcinema.com/contents/01/15/zhangke_interview.html. The idea of "a Jia Zhangke accent" is drawn from Lu Tonglin's discussion of modern Chinese cinema. See Lu, "The Zhang Yimou Model," in Confronting Modernity in the Cinemas of Taiwan and Mainland China, Cambridge, Cambridge University Press, 2002, pp. 157172.

9. In the context of this paper, I borrow the term "accented" from Hamid Naficy, An Accented Cinema: Exilic and Diasporic Filmmaking, Princeton, Princeton University Press, 2001.

10. Paul G. Pickowicz and Yingjin Zhang (eds.), From Underground to Independent: Alternative Film Culture in Contemporary China, Lanham, Rowman \& Littlefield Publishers, 2006, pp. vii-xi. 
24 City. In 2003, Jia, Yu, and Chow founded Xstream Pictures, a production company based in Beijing and Hong Kong that co-produced The World with Office Kitano, Celluloid Dreams, and Shanghai Film Studio. Its second production was Walking on the Wild Side (2006), a co-production with Les Petites Lumières directed by first-time filmmaker Han Jie. It won the Tiger Award (Best Film) at the 2006 Rotterdam International Film Festival. ${ }^{\text {(I) }}$

In its more recent phase, Jia's independent filmmaking is characterised by its tendency to corporatise rather than raise funds individually. He once remarked that "corporatisation" of filmmaking could protect directors' benefits, and that a good and strong production system would be beneficial for independent filmmaking, helping the spread of an independent spirit and the cultivation of young film artists. ${ }^{(12)}$ These changes in mode of filmmaking have marked a crucial transition from an individual's lone efforts to alternative ways of forming trans-border connections within the system of global capitalism. These alternative modes of corporatisation have opened up public space outside the terrain of the nationstate and across geopolitical boundaries. In light of this trajectory over the years, Jia can be seen navigating between private and public spaces to tell personal and collective stories of contemporary Chinese people.

Similarly the venues of exhibition and routes of circulation also underwent interesting changes during China's massive marketisation in the 1990s. Jia's earlier films were shown in private film societies, which were rapidly developing in China at that time, not always at formal exhibition venues but often at pubs, bars, and university campuses. Jia claims that the development of film culture began really taking off in 1995, when the first VCD stores opened in many cities of China. ${ }^{\left({ }^{(3)}\right.}$ That was also the time when DV became an increasingly important tool of artistic expression for young filmmakers who did not have access to expensive and technologyintensive equipment. Jia impressed the international audience with his DV productions, demonstrating a remarkable democratisation of film culture. A century ago, when Walter Benjamin discovered that film was a powerful agent shattering tradition and displacing the "aura" in an age of mechanical reproduction, he was already optimistic and hopeful about the emancipatory potential of film and technology. ${ }^{(14)}$ The use of DV by Jia and his peers has brought about a transition from an age of mechanical reproduction to an era of digital art. They have publicised the personal stories of ordinary people through a new technological medium. Their practice is comparable to other examples of independent filmmaking where film artists fight for access and recognition with the help of technology. It resonates with what can be called "the grassrooting of cinematic practices," when filmmakers such as Jia acquire artistic freedom through inexpensive technology and a practice from below. ${ }^{(15)}$

The festival circuit has been the main route through which Jia's films have accessed the international film scene. It is interesting to note that Naficy's accented cinema refers to "exilic, diasporic and ethnic" types of films. Noting that they may somehow overlap with each other, he focuses on filmmakers who share the experience of traversing geopolitical and cultural boundaries. The linguistic reference of "accent" as a signifier of difference carries much weight in his study of alternative films by selected directors, who came out of "the postcolonial condition of displacement" and the "postmodern setting of scattering." The accented style of such films, for all their variety, is augmented by their shared tendency to depict "tensions of marginality and difference." (16) In a comparative light, Jia's accented films are also in "diaspora," if the term is adopted to refer to the outflow of film texts and the internal migratory experiences of displaced workers across regions in China. Starting with Xiao $W u$, Jia's films have been exhibited in international film festivals all over the world: Berlin, Nantes, Vancouver, Pusan, Rotterdam, Cannes, Hong Kong, Venice-this list is not exhaustive. It is interesting to note that the popular reception of Jia's films in these renowned festivals demonstrates the power of realism as an aesthetic tradition in international art cinema. ${ }^{(17)}$ No wonder Jia's name is associated with Yasujiro Ozu, Hou Hsiao-hsien, and Andrei Tarkovsky in world cinema. It follows that the film festival as an institution shapes and is shaped by aesthetic and cultural values. It is a global institutional space that can be regarded as "a field of cultural production" in Pierre Bourdieu's sense of the term. ${ }^{(18)}$ Over

11. See http://www.newyorkerfilms.com/nyf/t_elements/stilllife/stilllife_pk.pdf.

12. See "Jia Zhangke: You huan yi shi shi wo xia juexin chengli Xihexinghui" (Jia Zhangke: A sense of crisis urged me to set up Xstream Pictures) at http://ent.sina.com.cn/c/200807-29/ba2118180.shtml.

13. Jia, Jia xiang, p.125.

14. Walter Benjamin, "The Work of Art in an Age of Mechanical Reproduction," in Hannah Arendt (ed.) Illuminations, translated by Harry Zohn, New York, Schocken Books, 1969, pp. 217-242.

15. See Esther M. K. Cheung, Chapter 2, "Authenticity and Independence: Fruit Chan and Independent Filmmaking" and Chapter 7, "Epilogue: Grassrooting Cinematic Practices," in Fruit Chan's Made in Hong Kong, Hong Kong: Hong Kong University Press, 2009, pp. 21-38 and pp. 125-127.

16. Naficy, An Accented Cinema, op. cit., p. 10-11.

17. Jason McGrath, "The Independent Cinema of Jia Zhangke: From Postsocialist Realism to a Transnational Aesthetic," in Zhang Zhen (ed.), The Urban Generation: Chinese Cinema and Society at the Turn of the Twenty-first Century, op. cit., pp. 81-114.

18. Pierre Bourdieu, The Field of Cultural Production, New York, Columbia University Press, 1993. 
the years, as Jia's international fame has escalated, the popular reception of his films has shaped what I refer to as "a cinema with an accent". His characters often speak Chinese with an accent or in a local dialect incomprehensible even to Chinese viewers, not to mention the international audience. With sight, sound, and poetry, Jia's films weave together a tapestry of visual memories reflecting the unprecedented transformations in post-socialist China. His characters' personal stories, often told from the point of view of ordinary grassroots people, acquire broader resonances within the changing reality in China. Their sense of homesickness and uprootedness shapes a structure of feeling intimately associated with the psychological consequences of incessant urban demolition and construction. Intriguingly, it is no coincidence that Jia's glowing significance in global art cinema parallels the rise of China in the international political scene since 1989. Unlike contemporaries such as Zhang Yuan and Lou Ye who are more rebellious and edgy, Jia appeals to his international festival audience through his humanitarian concern for the underprivileged caught up in the unprecedented tidal waves of marketisation in post-socialist China. As fields of cultural production, many film festivals in varying degrees reinforce moral humanitarian values by giving awards to screen productions that express demands for social justice and concern for society's underdogs. Unlike the Fifth Generation filmmakers who produced self-orientalised images of China for global consumption, Jia's realistic film style and concern for the underprivileged have enabled him to accumulate cultural and symbolic capital within the film festival field of production. Recently he has continued to shape and sustain this independent film culture to cultivate new talent as his cultural and symbolic capital has translated into economic capital. In 2009, Jia announced at the Pusan International Film Festival that his production company Xstream Pictures would finance South Korean newcomer Baek Seung-Hoon to direct a comedy called Flying Duck. He has conceived of a new-director scheme to sponsor four new films to benefit young talents in Asian cinema with 100 million yuan (US\$14.7 million) in funding raised by Xstream Pictures. ${ }^{(19)}$ Within the anonymous global system, Jia's independent filmmaking has entered a corporatised stage in which personal and individual significance continues to be asserted, demonstrating that cultural productions can transcend the circulation of capital and resources, and that moral, cultural, and aesthetic values play a prominent role in shaping contemporary Chinese film culture today.
In my previous work on Hong Kong cinema, I have argued that at critical times, filmmakers resorted to surreal and ghostly elements to articulate their sense of disjointedness and disorientation. ${ }^{(20)}$ In relation to the films of Jia and other members of the Urban Generation, this statement can be modified to say that the breakdown of sequential chronological time gives rise to the importance of the personal and the authentic. In Western discourse on urbanity, the opposition between the individual and the collective is well-established in the work of Georg Simmel and the Chicago School. The notion of the individual is perceived as instrumental to countering the anonymous outside forces. This strand of thought clearly shows the influence of the Western tradition of individualism since ancient Greece. Along this line, contemporary debates on globalisation have offered local resistance and personal narratives as responses to challenge the hegemony of globalisation.

Jia's personal and authentic approach is similar to this challenge-response pattern, although the notion of individualism in post-socialist China is even more complex than the Western dichotomy between the personal and the collective. While Jia's characters are unlike Western classical Promethean heroes, as argued before, his personal and authentic films are a dual reaction against the burden of the historical legacy of the Cultural Revolution generation and against external homogenising global forces and domestic chaotic transformations. From the post-Mao era of cautious reform to the wholesale structural changes after 1989, the cultural space of China has not been easy to comprehend and represent artistically. Although this mutable space is a great challenge, Jia has ceaselessly sought to make sense of this absurd drama of history. From his hometown of Fenyang to Datong, from Fengjie in the Three Gorges region to the theme parks of Beijing and Shenzhen, and more recently from Shenyang to Chengdu, Jia's film imagery signifies a world in a constant state of destruction and construction. It is a world frequented by disoriented pickpockets, drifting artists, disaffected youth, depressed migrant workers (min gong), and the like. It is a landscape of urban ruin produced through sudden ruptures. Within this landscape, although the individual is not always rescued, he or she always struggles against the mu-

19. See "Jia Zhangke to finance Korean new director," Cultural China, http://news.culturalchina.com/ 20091016155508.html.

20. Esther Cheung, "On Spectral Mutations: The Ghostly City in The Secret, Rouge, and Little Cheung," in Kam Louie (ed.), Word and Image in Modern Hong Kong Culture: Does 1997 Matter? Hong Kong, Hong Kong University Press, forthcoming. 
table world outside, develops new subjectivities, and seeks out new solidarities.

\section{A Jia Zhangke accent: Realisms within a conundrum}

Studies of autobiographical and documentary films often emphasise the importance of three sets of inter-related values: truth, identity, and action. ${ }^{(21)}$ In a certain way, Jia's ethics of the personal and the authentic can be deciphered by a similar tripartite schema. As demonstrated by their strong authentic appeal, Jia's films urge us to explore the value inherent in his realistic mode. Truth and authenticity in film art are associated with the claim of being consistent with historical reference and evidence. Given the ontological status of film, this value persuades or guides viewers to perceive the mediated reality of the film apparatus as real and historical. Spectators are often impressed by Jia's use of on-location settings, amateur actors, hand-held cameras, and naturalistic sound, all of which render a strong historical sense of immediacy and reality. However, the most important thing about Jia's films is not simply a matter of film style and assembled realistic traits. Neo-formalist film critics are right to point out that realism is better understood as "realistic motivation" than as style alone. The latter may lead us to fixate on a set of unchanged traits, while the former refers to how filmmakers perceive their work against shifting norms. "Motivation," as related to "intentionality," is almost taboo in the poststructuralist context, where the Author-God has been summoned to death. In the field of independent filmmaking, however, practitioners' motivation to represent reality has become pivotal to our understanding of their films. In this case, "motivation" manifested in textual and formal features embodies the filmmaker's intention to create the effects of the real. Kristin Thompson thoughtfully argues that realism can be "radical and defamiliarizing if the main artistic styles of the time are highly abstract and have become automatized." "22) From Xiao Wu to 24 City, Jia has been engaged in a constant process of aesthetic debate to negotiate and re-negotiate the norms of realism.

In his meticulous study of Jia's films, Jason McGrath rightly notes a clear transformation in his realistic film style over the years. Jia's earlier films are characterised by an experimental and direct-cinema style with a lot of rough edges, and share a post-socialist structure of feeling with other documentary and fiction filmmakers of the 1990s. His later films show a stylised long-take realism that places him safely in the tradition of international art cinema. ${ }^{(23)} \mathrm{Mc}$ Crath's view on the relationship between Jia's long-take realism and his international recognition echoes my previous argument about the film festival as a field of cultural production. More importantly, this assertion illustrates that Jia and other Urban Generation filmmakers have no choice but to negotiate their aesthetic and cultural positions within the global-local nexus when China has sailed into the turbulent sea of market economy.

While Jia may differ from other contemporary filmmakers of his generation such as Lu Chuan and Zhu Wen, he shares with the new documentarists an earnest quest for authenticity. In this discussion of film style, taste formation, and global-local relation, what should also be emphasised is the dissemination of value, be it moral, aesthetic, and cultural. As argued before, realism is not merely an assembly of traits but a set of stylistic cues that guides us in grappling with the filmmaker's realistic motivations. Jia's realism is a form of self-empowerment that enables him to participate in the competing discourses of post-socialist China and the global film scene. His emphasis on constructing the visual memories of his generation articulates the urgent need for recognition among subaltern groups of people and the demand for justice. This advocacy is close to what Charles Taylor calls "the politics of recognition." While it is important to point out that Jia and the Urban Generation do not represent a homogenous organised political cinematic movement, the value of authenticity in Jia's case is inherent in this fight for the right to speak for his generation. As Taylor asserts, any fight for recognition is directed against a "Significant Other" outside the self. ${ }^{(24)}$ Jia's films represent a clear desire to compete with, if not displace, the Fifth Generation. What is more, his alignment with film auteurs such as $\mathrm{Hou}$ and $\mathrm{Ozu}$ and the art-house tradition is another case in point. It is clearly an endeavour to showcase alternative modes of film viewing in a world dominated by Hollywood and commercial filmmaking.

To articulate the sense of temporal disjointedness in contemporary China, Jia situates his characters in real locations among devastated urban spaces. In $X i a o W u$, for example,

21. See Jim Lane, Chapter 1, "The Convergence of Autobiography and Documentary: Historical Connections," in The Autobiographical Documentary in America, Madison, University of Wisconsin Press, 2002, pp. 11-32.

22. Kristin Thompson, Breaking the Glass Armor: Neoformalist Film Analysis, Princeton, NJ Princeton University Press, 1988, p. 198.

23. McGrath, "The Independent Cinema of Jia Zhangke: From Postsocialist Realism to a Transnational Aesthetic."

24. Charles Taylor, "The Politics of Recognition," in Amy Gutmann (ed.), Multiculturalism: Examining the Politics of Recognition, Princeton, Princeton University Press, 1994, pp. 25-73.

25. See Sheldon H. Lu, "Postscript: 1999," in China, Transnational Visuality, Global Postmodernity, Stanford, Standford University Press, 2001, pp. 261-268. 
Still Life tells the story of coalminer Sanming (Han Sanming) and nurse Shen Hong (Zhao Tao), who come from Shanxi to Fengjie in hopes of reuniting with their spouses. ๑ Xstream pictures

Jia examines post-socialism as a cultural logic charged with discrepancies between aspirations for neo-liberalism and nostalgia for negotiating with a residual socialist past. ${ }^{(25)}$ The film tells the story of a young pickpocket Xiao $\mathrm{Wu}$ in Fenyang, Jia's hometown, who faces the breakdown of his relationships with his family, friends, and a woman when he cannot break with his criminal past. Fenyang is portrayed as a provincial town caught up in a world of discontinuities where demolition is everywhere and socialism has lost its credibility. The film's authentic appeal, enhanced by the use of edgy hand-held camera and on-location shooting, gives rise to the opportunity to articulate the individual's historicity. Xiao Wu negotiates his present with a discontinuous past that is disappearing or that reappears only in the nostalgic reconstruction of consumer culture. The Maoist portrait at the outset of the film brings about a contradictory situation in which the characters may benefit from the residual influence of Maoism in contemporary China but must grapple with its inevitable loss of legitimacy ${ }^{(26)} \mathrm{As} \mathrm{Xiao} \mathrm{Wu}$ is subject to the imminent threat of erasure in a fast-moving city, his everyday existence in post-socialist China is manifested in his personal struggle against the ruthless symbiosis of (global and state) capitalism and socialism.

An equally captivating example is found in Still Life, a film about two people, coalminer Sanming and nurse Shen Hong, who come from Shanxi to Fengjie in hopes of reuniting with their spouses. We witness them walking through the rubble and ruin of Fengjie searching for their lost loves as demolition is taking place at the Three Gorges. Spectators hear actual hammering sounds and see the real action unfolding as they accompany the characters on their search. This device conveys an impressive sense of immediateness and reality by approximating real time and proximity to real place. As evoked in cinéma vérité, it reminds viewers that historical observations are vividly derived from lived reality. The value of authenticity in Jia's films is not restricted to the two types of realism that McGrath delineates. As generally noted by many viewers, the insertion of surrealistic elements into his films is very intriguing. As Jia is always aware of the constraints of realism, he is fond of mixing fictional and surreal elements with the real. The employment of surrealist cues such as the taking off of the memorial structure and the tight-rope walker traversing the Three Gorges at the end of Still Life are just some familiar examples illustrating his deviation from realism. 24 City is a semi-documentary manipulating fiction and reality to construct a historical interpretation. Flash-style animation interludes and colourful dance sequences in The World reveal Jia's interest in crossing
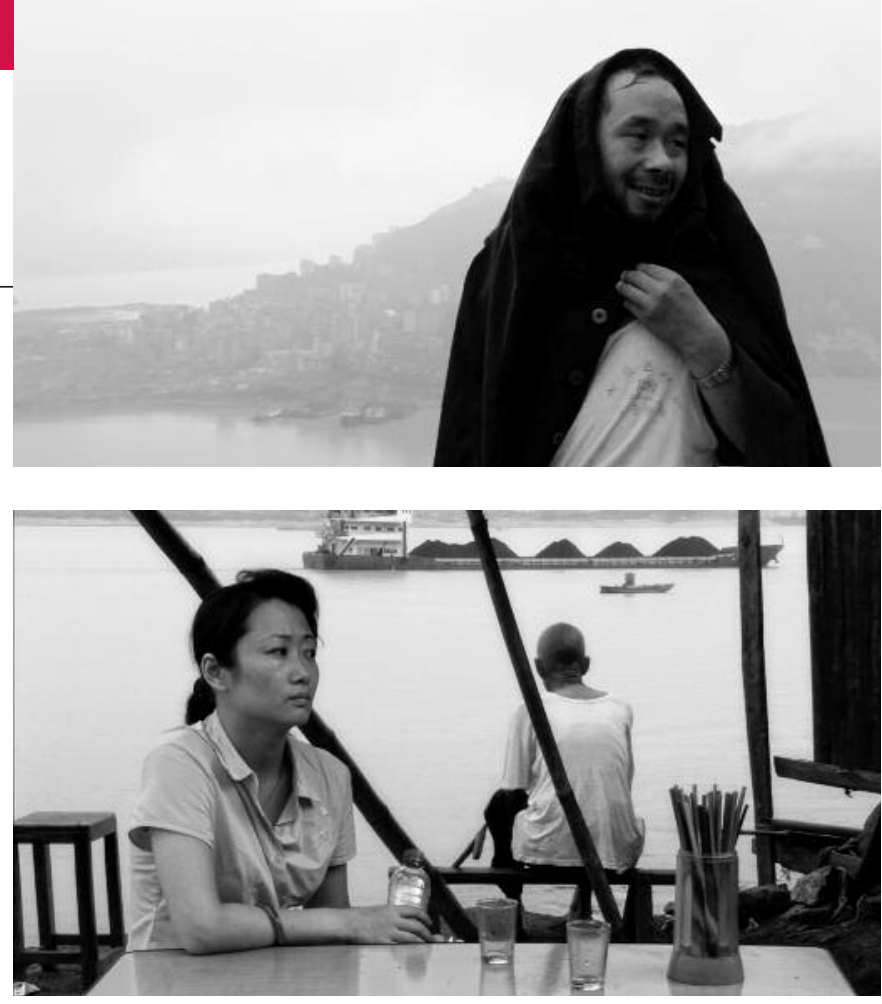

generic boundaries. In fact, his endeavours to interweave the real with the fictional bring forth a complex but fundamental philosophical question about knowing, experience, and representation, which sheds light on issues about values and ethics as well.

In an interview on the making of The World, Jia expresses his sense of disorientation at a disjointed time when China is shifting from the post-Mao era of cautious reform to the wholesale structural changes after 1989. Like a conundrum, the cultural space of China generates a feeling of bewilderment and challenges the representational potentialities of film art:

I live in Beijing. Since 2000, the rhythm of the city has greatly accelerated. There are construction sites everywhere. There is no clear demarcation of time or season. Time and space are being compressed. There is simply too much information to digest, about friends, new things, materialistic desire or lack of it (...). We are being sucked into a vortex. ${ }^{(27)}$

The speedy process of demolition and construction has produced not only space-time compression but also space-time dislocation. The consequences of sensory overload on the mental life of urbanites are so daunting that one may readily

26. Lin Xiaoping, "Jia Zhangke's Cinematic Trilogy: A Journey Across the Ruins of Post-Mao China," in Sheldon H. Lu and Yueh-Yu Yeh (eds.), Chinese-Language Film: Historiography, Poetics, Politics, Honolulu, University of Hawaii, 2005, pp. 186-209.

27. Huang Jing, "Jia Zhangke kaifang shijie" (Jia Zhangke opens up The World), Wen We Po, 6 April 2005, p. C01, http://paper.wenweipo.com/2005/04/06/RW0504060001.htm.

28. Georg Simmel, "Metropolis and Mental Life," in Donald N. Levine (ed.), Multiculturalism: Examining the Politics of Recognition, Chicago and London, The University of Chicago Press, 1971, pp. 324-339.

29. Andrew Chan, "Moving with the Times," Film Comment, March/April 2009, http://filmlinc.com/fcm/ ma09/uncutjia.htm. 
recall Georg Simmel's explication of the nature of metropolitan life about a century ago. ${ }^{(28)}$ In another instance Jia asserts that the changing reality of post-socialist China is indeed surreal in nature:

I think surrealism is a crucial part of China's reality. In the past 10 years, China has experienced the kinds of changes that might happen across a span of 50 or even 100 years in any normal country, and the speed of these changes has had an unsettling, surreal effect. For example, in The World, the World Park setting in Beijing is itself a fantasy (...). ${ }^{(29)}$

If drastic mutations in reality are surreal and fantastical, what is the best representational mode for depicting this conundrum? In some ways, the mixing of the real and the unreal is not only a departure from the vérité mode of his earlier films but also an interpretive endeavour to make sense of the changing reality in post-socialist China. Aesthetically this mixed mode cannot be strictly regarded as documentary realism, but it expresses a similar hermeneutic stance borne by realist and documentary filmmakers. In the first instance, it acknowledges one's own ontological limitation of knowing the truth, let alone the whole truth, in a maze-like situation; this is especially challenging when one is being "sucked into a vortex." It follows that one is unable to interpret one's own history because of its temporal proximity. However, this epistemological constraint has never deterred artists from the urge to make sense of reality. The common practice for realists and documentarists is to bring reality closer through their edgy and vérite lenses-to record what is happening on the spot, so to speak. Similarly, Jia's adoption of the techniques of defamiliarisation provides an avenue for viewers to get in touch with reality. Neo-formalist film critics are right to suggest that "realistic motivations" that can be "defamiliarising" are not a fixed set of realistic traits. Jia's camera thus records and makes strange at the same time to produce a visual hermeneutics of China's contemporary reality.

Like abstract symbols in the tradition of surrealist art, Jia's mixed images invite viewers to generate open-ended interpretations of the absurd post-socialist conundrum. These mixed images are closer to Rene Magritte than Salvador Dali; instead of the Dali-esque style of surrealism typified by the well-known melting clock, Jia's mode of defamiliarisation is similar to Magritte's ironic and absurdist juxtaposition of elements with meticulous realism. In Jia's films, when the surreal intrudes into the real world, its fluid, naturalised entry is similar to the seamless merging of different realistic elements in Magritte's paintings. Jia once explained why the feature Still Life was made after the documentary film Dong (2006), which followed the artist Liu Xiaodong while he painted near the Three Gorges Dam and later in Bangkok. He says, "It is not a bad thing to learn about the limitations of documentary." ${ }^{(30)}$ While it is true that documentary films have been perceived as creative interpretations of actuality ever since John Grierson's declaration, feature films derived from documentary predecessors show a greater leap into the hermeneutic realm. ${ }^{(31)}$

As Jia himself claims, The World depicts post-socialist China as being as surreal and fantastical as its theme parks. The film revolves around the love-hate relationship of Xiao Tao and Tai Sheng, two young people who work at a theme park along with their friends. It was filmed on the World Park on the outskirts of Beijing, which presents scaled-down replicas of world landmarks such as the Eiffel Tower, the Pyramids, and even New York City's Twin Towers. In his discussion of the hyperreality of Disneyland, Jean Baudrillard critiques the nature of history and memory in today's postmodern world:

Disneyland is a perfect model of all the entangled orders of simulacra. It is first of all a play of illusions and phantasms: the Pirates, the Frontier, the Future World, etc. This imaginary world is supposed to ensure the success of the operation.... Disneyland: a space of the regeneration of the imaginary as wastetreatment plants are elsewhere, and even here. Everywhere today one must recycle waste, and the dreams, the phantasms, the historical, fairylike, legendary imaginary of children and adults is a waste product, the first great toxic excrement of a hyperreal civilisation. On a mental level, Disneyland is the prototype of this new function. ${ }^{(32)}$

The reproduction of theme parks in China is an intriguing phenomenon because it articulates an oblique China-West relationship within the context of global capitalism. Before Disneyland's recent investment, the World Park in Beijing, and the Window of the World and Huaqiao City in Shen-

30. Sandra Shih, "TIDF documents 129 versions of reality," Taiwan Today, 17 November 2006, http://www. taiwantoday.tw/ct.asp?xltem $=23486 \& C t N o d e=430$

31. John Grierson, "First Principles of Documentary," in Kevin MacDonald and Mark Cousins (eds.), Imagining Reality: The Faber Book of the Documentary, London, Faber and Faber, 1996, pp. 97-102.

32. Jean Baudrillard, Simulacra and Simulation, translated by Sheila Faria Glaser, Ann Arbor University of Michigan Press, 1994, pp. 12-13. 
Fig. 1. Who are those people on the plane? (The World) (c) Xstream pictures

zhen were built to entertain and enable Chinese people to get in touch with the outside world through their simulacra. If Disneyland recycles childhood fantasies and memories for American people, the theme parks in China appeal to Chinese people's desire to be global and on par with the West. The almost real-size reproduction of the Swiss resort town of Interlaken in Shenzhen's Huaqiao City is an even more blatant form of recycling "other" people's "experience" and "memory." ${ }^{(33)}$ As Shelly Kraicer observes, the film critiques this postmodern hyperreal condition:

While The World is grounded on a specifically Chinese experience, ruthlessly dissecting contemporary urbanity as it is incarnated in today's Chinese metropolises, its title signals a more expansive ambition (...).The film satirizes a post-Benjaminian culture where copies assume primary validity, become even more "authentic" than putative originals. ${ }^{(34)}$

In The World, Jia exposes this absurdist condition by shifting the point of view from the consumers to those who work for the theme parks. If consumers of theme parks in China experience a homogenising tendency of global capitalism, the labourers who service the theme parks are bewildered by their exclusion from this global game. The classic Marxist notion of alienation stands out in this case. In a scene at a construction site, while watching an airplane, the migrant worker nicknamed "Little Sister" asks Xiao Tao who those people are on board. Both of them lament the fact that they have no idea, because they have never been on the plane before (see Fig. 1). While the advertising slogan claims that one can " $[t]$ ravel around the world without leaving Beijing," the film exposes the fact that those who satisfy the tourist gaze can be trapped in their lower-class stratum. Little Sister's simple and innocent question provides a melancholic foreboding of his later tragic death at the same construction site.

Just as the underprivileged experience a sense of loss and entrapment within the tidal waves of post-socialism, relatively more mobile people are equally bewildered in the whirlwind of change. In Still Life, Hong and Sanming both witness the tightrope walker treading his surreal and precarious path across the Three Gorges (see Fig. 2). Both characters are in search of their lost past while grand modernisation projects are eliminating the homes of others. These two examples pose a huge challenge not only to ordinary people like Xiao Tao, Little Sister, Hong, and Sanming but also to cultural critics and contemporary thinkers. The cultural

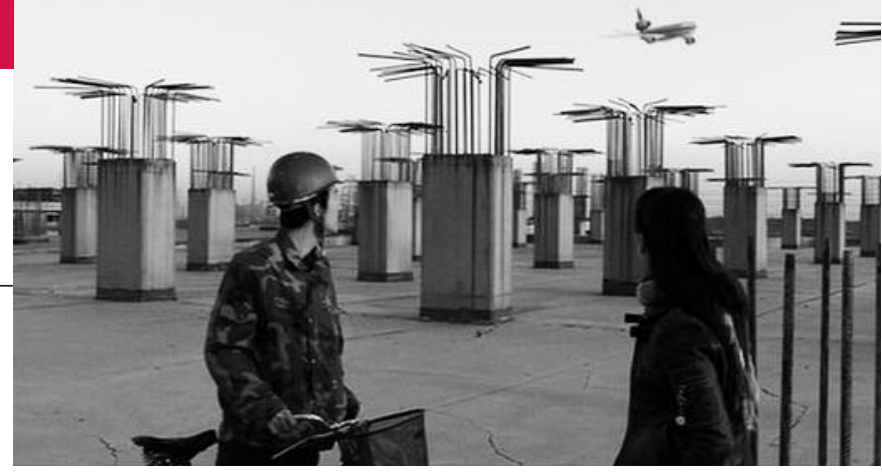

space of China is plagued by a chaotic flow of temporalities. Western modernity in China does not precede the postmodern hyperreal; they coexist easily within the same space while posing a challenge to the people adrift in post-socialist China. On the level of representation, it follows that many similar subtle mutations experienced on an everyday-life level can only be made visible and blatant through the use of surreal images.

\section{The values of identity and performance}

In this state of utter confusion, the values of identity and performance that are central to Jia's films hinge on the biographical historicity of the individual. ${ }^{(35)}$ By this, I do not mean biography as an historical and chronological record of an individual; in fact, some of Jia's films deal with a fictional persona rather than an autobiographical figure. What is most important is that they performatively produce new perspectives of interpreting history. The films of Jia's "Hometown Trilogy," Xiao Wu, Platform, and Unknown Pleasures, sometimes contain an implicit "autobiographical pact" between the filmmaker and the protagonists, but the biographical personae are often fragmented into a narrating subject and a narrated object. In this way, the personal appeal of Jia's films does not lie in the validity and dramatic nature of an individual's experience; instead, his characters epitomise a generation or represent a moment of transition in what Wang Hui calls a "collective image" (qun xiang). ${ }^{(36)}$ As mentioned before, Jia's films appeal to contemporary Chinese intellectuals such as Wang who are concerned with the fate of the country's (post)/modernity. In an effort to assert that the historicity of this group portrait bears no heroic accomplishments and to portray ordinary people subject to the tides of change, Wang and others have turned away from the official celebratory discourse to focus on the most grassroots fundamental level. Many impressive scenes in the "Hometown Trilogy" place the characters in a panoramic landscape. Up-

33. See official website of Huaqiao City: http://www.chinatravelguide.com/ctgwiki/ Huaqiao_City.

34. Shelly Kraicer, "Lost in Time, Lost in Space: Beijing Film Culture in 2004," Cinemascope 21, http://www. cinema-scope.com/cs21/feat_kraicer_beijing.htm.

35. The term "the value of identity" is drawn from Lane, The Autobiographical Documentary in America, but in his essay, "act value" instead of "performance value" is used.

36. Wang Hui, in Ouyang Jianghe (ed.), Zhongguo du li dianying fang tan lu (On the Edge: Chinese independent cinema), Hong Kong, Oxford University Press, 2007, p. 264. 
rooted and aimless young people such as Bin Bin, Qiao Qiao, and Xiao Ji from Unknown Pleasures drift aimlessly in the space of the mutable city. One of the most representative images comes from $\mathrm{Xiao} W u$, when the title character stands in the background as fast-moving traffic speeds past in the foreground. This interesting mise-en-scène turns the moving city into the protagonist while treating the character like stationary ruins in the backdrop. ${ }^{(37)}$

This performance is made possible by the adoption of what Gilles Deleuze calls "time-movement," which contrasts with images of movement in the Hollywood tradition. Together with other contemporary Chinese filmmakers, Jia's aesthetics show "a general resurgence in interest in issues of time in Cinema Studies as a whole, with the rise of Deleuzian theory and awareness of time as a construct rather than a given." (38) It is the constructed nature of time that makes performative identity possible. When these characters drift through the old neighbourhoods of their cities, they themselves become part of their ruined environment. If the old neighbourhoods are disappearing, they are also subject to decay and immobility. The tragic deaths of Tai Sheng and Xiao Tao in The World suggest a fatalistic end to these drifting, homeless characters in the big surreal theme park of a postmodern world. However, Jia is not definite and altogether pessimistic about their final destiny. Others, such as the disoriented artists Cui Mingliang and Yin Ruijuan in Platform, adjust to the current of global change, and their destiny is open-ended at the end of the film. Han Sanming's search for his old love in the vanishing Fengjie signifies what one can preserve and hold on to in an endless process of destruction. One may even consider this view as a "vision of embodied resistance-an individual, physical resilience that can spark an impossible, miraculous, but tangible hope in a world that seems to offer none." ${ }^{(39)}$

To deliver this collective image of ordinary people, Jia has to make a historical interpretation of China's changing reality performatively. For a film artist, unfolding an action that exemplifies the character's responsibility for that action and showing how it is performed in specific space and time is a matter of decision and interpretation of history. It is through selection and artistic design that a filmmaker can grapple with the value of performance. The screened reality in his films is therefore always ascribed to embodiment, subjectivity, and historicisation. It is interesting to note that Jia's films, especially his earlier ones, are characterised by an attempt to interpret history through silence and observation. There is a total absence of a governing

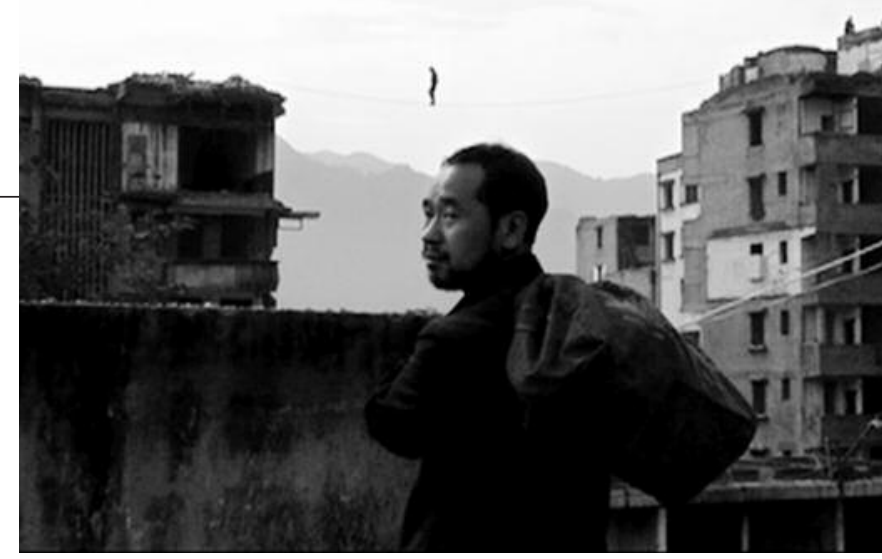

narrative voice. Subjectivities are often embodied in inarticulate individuals. Xiao $W u$ is a prime example. Jia and his cinematographer play the role of bystanders, observing how events unfold in the streets to preserve the rough edges and the on-the-spot mood. In Platform, a series of long takes or panoramic shots maintains distance between the camera and the people being observed. Such a distance creates a lot of elliptical space for viewers to make their own interpretation. Since the characters themselves are quite reticent, we as viewers have the impression that silence conveys the filmmaker's incomplete understanding of the mutable reality, and observation is a means through which he comes closer to his observed reality. In other words, we suspect that the filmmaker is not willing to draw hasty conclusions about the conundrum of contemporary China. One can also claim that silence is a minimal form of performance. It does not render an outright rejection of performativity; rather it delivers restrained authorial commentary and interpretation within an enigmatic state of post-socialist China, leaving the topic of global capitalism open-ended and exploratory. This open attitude is often found in Jia's films, which seldom adopt a totally anti-globalisation stance in spite of their obvious compassion for the underprivileged. This way of performing and interpreting history corresponds to Jia's own claim that he prefers to return to the stage of cinematic primitivism represented by silent film: "I am very fond of silent films. They are very original and first-hand (...). Each light, each movement or scene is achieved with industrial precision." (40) However, in more recent films such as 24 City, which chronicles the lives of three generations of workers in a state-owned munitions factory that will be shut down to make way for a luxury apartment complex, the camera focuses on characters who use language to articulate nostalgic thoughts and feelings, especially in the fictional parts of the film. In contrast, the awkwardness of some inartic-

37. Chris Berry, "Xiao Wu," Cinemaya 42 (1998/99), p. 20.

38. Chris Berry, "One Film at a Time-Again," [Introduction] in Berry (ed.), Chinese Films in Focus II, Hampshire and NY, a BFI book published by Palgrave Macmillam, 2008, pp. 1-8.

39. Shelly Kraicer, "Chinese Wasteland: Jia Zhangke's Still Life," Cinemascope 29, http: www.cinemascope.com/cs29/feat_kraicer_still.html.

40. Teo, "Cinema with an Accent—Interview with Jia Zhangke, director of Platform." 
ulate interviewees under the spotlight may reveal the tyranny of the camera, as one critic remarks. ${ }^{(4)}$ Despite all this, it can be generalised that Jia's films privilege silence, observation, and contemplation as ways of responding to contemporary Chinese history.

Furthermore, Jia provocatively connects the historicity and authenticity of his characters to the material and anthropological dimensions of everyday life. In Still Life, as one critic notes, four categories of objects, including cigarettes, wine, candy, and tea, highlighted by intertitles without glamour or exaggeration, strike us as mundane parts of an ordinary inhabitant's daily rituals. ${ }^{(42)}$ But here these daily rituals are performed by materially impoverished lower-class people. Those who are affluent probably have more time to indulge in materialism than to appreciate the meanings of materiality. For the workers, even a 10 RMB note provides an emotional connection with their homelands. In one scene, when the workers at the demolition sites search for familiar places on the currency, it suggests that one can make connection with a larger landscape through material objects. Apart from being daily necessities, these mundane objects convey a different sense of materialism in post-socialist China. While commodities in prosperous global cities are fetishes that signify status, material success, and capitalistic desires, these quotidian objects create emotional alliances among the characters themselves, as well as across geo-cultural boundaries. This new materiality, rooted in lived experience, suggests an alternative means of forming attachments in global cities dominated by incessant desires for material possession.

In light of the above three values, we can say that the subject matter of social concern and Jia's compassion for the ordinary people place him safely in the realist tradition of Chinese cinema. His ethics of the personal and the authentic enhance his own auteurist stance and a "Jia Zhangke accent." However, his films lack the optimism and utopian impulses of socialist realism, which glorifies the proletariat's struggle toward socialist progress; instead, Jia is more interested in depicting the plight of ordinary people in the midst of unprecedented social mutations. Furthermore, unlike some types of realist works, Jia's films do not articulate explicit anti-Western, nationalistic sentiments as counter-discourses to the waves of post/modernisation. Instead, they adopt a more self-reflective stance toward such "encroachment," at times revealing the insiders as complicit, docile, and helpless. Many of his characters have no choice but to swim with the tide of globalisation, consuming commodities and "benefiting" from global capitalism while at the same time suffering from its uneven development. Even the artisanal characters in his film worlds are not always upbeat and never heroic. Gradually and systematically, the "national" is displaced in his film discourse of the urban, where nostalgic urban dwellers lament the passing of time in the ruins of their cities.

In more than a decade, Jia's persistent cinematic oeuvres remind us of some lines from a poem that he himself cites in 24 City. In "Spilt Milk," W. B. Yeats writes:

\section{We that have done and thought, \\ That have thought and done, \\ Must ramble, and thin out \\ Like milk spilt on a stone. ${ }^{(43)}$}

The milk spilt on a stone may be too sad an image to evoke, but Jia's determination and persistence in enabling ordinary people to "ramble," whether in silence or in words, about what they have thought and done has injected values and vision into contemporary film culture, playing out a passionate ethics and politics of the personal and the authentic.

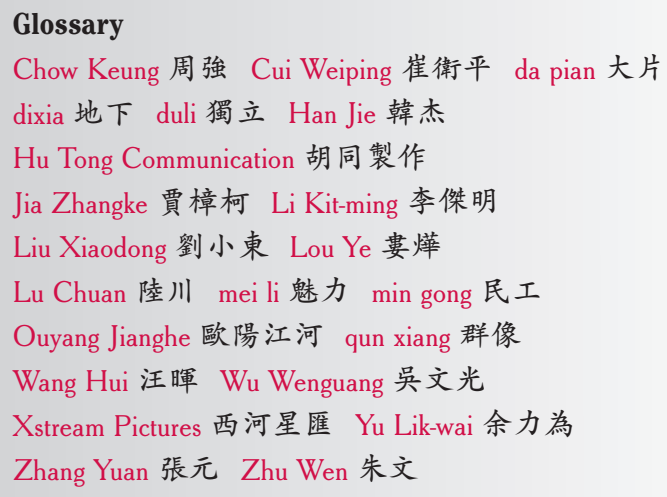

41. See Feiyufeiyu's review of 24 City, "Jin ni xiaoshi de yimian" (Just the side you have erased), http://www.douban.com/review/1801488/.

42. Wang Hui, in Ouyang (ed.), Zhongguo du li dianying fang tan lu (On the Edge: Chinese Independent Cinema), p. 261.

43. W. B. Yeats, "Spilt Milk," in Richard J. Finneran (ed.), The Poems: A New Edition, London, Macmillan, 1983, p. 240. 